\title{
Oral health status in a Lebanese geriatric population
}

Sandra E. Andari, ${ }^{1,2}$ Lilian A. Ghandour, ${ }^{1}$ Monique Chaaya ${ }^{1}$ and Joseph G. Ghafari²,3

${ }^{1}$ Department of Epidemiology and Population Health, Faculty of Health Sciences, American University of Beirut, Beirut, Lebanon (Correspondence to: L. Ghandour: lgo1@aub.edu.lb). ${ }^{2}$ Division of Orthodontics and Dentofacial Orthopedics, American University of Beirut Medical Center, Beirut, Lebanon. ${ }^{3}$ Department of Orthodontics, University of Pennsylvania, Philadelphia, The United States of America

\begin{abstract}
Background: The sustained growth of older people and the epidemiological shift from communicable to chronic health problems have attracted increased attention to geriatric wellbeing, including oral health.

Aims: To evaluate the oral health of urban community-dwelling older people and identify their priority oral health needs.

Methods: We recruited 352 adults aged $\geq 65$ years in 2015 from social organizations and primary healthcare centres in Beirut and its suburbs. Older people underwent dental examination including the decayed, missing and filled teeth (DMFT) score, gingival health [plaque index (PI) and Periodontal Screening and Recording (PSR)], and dental functional units (FUs). Sociodemographic data were gathered through a structured questionnaire in a face-to-face interview. The participants were stratified into 3 age groups, and according to restoration with partial, complete and no dentures. Statistical analyses included the Mann-Whitney, Kruskal-Wallis and $\chi^{2}$ tests to explore the oral health status by sociodemographics.
\end{abstract}

Results: Missing teeth contributed most to high DMFT score . Mean PI and root caries indices were high. Mean FU scores were low, but higher in women and in complete denture wearers. Lower numbers of remaining mandibular anterior and maxillary posterior teeth, higher DMFT scores, but better periodontal status (lower PSR scores) were found in the older age groups. The more educated participants exhibited the healthier scores.

Conclusion: We observed poor oral health, particularly missing teeth and low FUs, in older people, warranting interventions to integrate oral health within the scope of geriatric general health.

Keywords: oral health, geriatrics, Lebanon, Lebanese elderly, community-dwelling, urban elderly.

Citation: Andari SE; Ghandour LA; Chaaya M; Ghafari JG. Oral health status in a Lebanese geriatric population. East Mediterr Health J. 2022;28(6):425433. https://doi.org/10.26719/emhj.22.034

Received: 08/12/20; accepted: 29/11/21

Copyright (C) World Health Organization (WHO) 2022. Open Access. Some rights reserved. This work is available under the CC BY-NC-SA 3.o IGO license (https://creativecommons.org/licenses/by-nc-sa/3.o/igo)

\section{Introduction}

The number and percentage of people aged $\geq 65$ years are increasing fast worldwide (1); a demographic change that is paralleled by an epidemiological transition or a shift from communicable to noncommunicable diseases, including oral health problems (2). These demographic and epidemiological developments have raised interest in the oral health status of geriatric populations given the comorbidities associated with edentulism and denturerelated conditions (3). The ensuing compromised masticationperformancehasbeenassociated withpotential effects on gastrointestinal health (4). Oral health affects geriatric quality of life because of compromised diet (e.g. inadequate mastication), limited social interactions (e.g. affected smile and speech) and ill health when oral problems increase the risk of frailty and disease (e.g. cancer) (3).

The main reported sociodemographic factors affecting geriatric oral health include age and gender, because oral healthdeteriorateswithage,especiallywithincreasedtooth loss (5) and periodontal problems (6). Although women report more barriers to seeking oral care, their compliance with and the success of oral treatment are significantly higher than in men (7).
The global trends are observed in Lebanon, where the older population is expected to reach $10.2 \%$ by 2025 and $23 \%$ by 2050 , which are the highest percentages in the Eastern Mediterranean and Arab Regions (8). Similar to otherdeveloping countries, attentiontogeriatricoralhealth has been minimal in Lebanon (9-11). Available studies have mainly focused on institutionalized (12) or careseeking (13-16) older adults, with only 2 research groups targeting community-dwelling older people in Lebanon. One focused on the rural community $(17,18)$ and the other targeted a non-treatment-seeking, community-dwelling urban Lebanese geriatric population (19). The limited studies on Lebanese older people have underlined the high burden of oral problems among them, mainly related to missing teeth and unrestored edentulism $(16,18,19)$, dissatisfaction with oral health status $(12,15)$, and poor oral-health-related quality of life $(14,16)$.

The aim of this study was to assess the oral health of community-dwelling Lebanese older people using a comprehensive range of indicators, and to identify priority oral health needs of this population.

\section{Methods}

This cross-sectional study included 352 people aged $\geq$ 65 years, recruited over 5 months in 2015 from 19 social 
organizations in Greater Beirut. These organizations provide a social setting for activities and games (e.g. playing cards and backgammon tournaments) as well as free food and clothes to people from low to moderate socioeconomic backgrounds. Some of the centres also deliver free healthcare services on specific days, which did not coincide with our visiting days.

The Ministry of Public Health manual on existing social and medical organizations serving older people was carefully reviewed. Of 28 eligible centres/organizations that were identified, 19 (68\%) that did not provide in-house dental services agreed to participate. The administrators of the cooperating centres were visited prior to data collection and the procedures were explained in detail before the centres agreed to participate.

An a priori calculation was performed to estimate the adequate sample size, although sample size calculation is typically not conducted with nonprobability convenient sampling. The calculation determined that 350 participants were needed, with a confidence interval of $95 \%$, power of $80 \%$, marginal error of $5 \%$, and prevalence of plaque index (>2) of $35 \%$.

A decision-making competency, assessed through a postconsent quiz, was first performed by the examiner to confirm that all recruited participants had intact cognitive faculties, comprehended the nature of the investigation, and could consciously consent to join the study (20). Subsequently, a face-to-face interview was conducted by an examiner using a structured questionnaire to collect sociodemographic data (e.g. age, gender and educational level). The questionnaire was developed by the research team in Arabic, and took about 10 minutes to complete. A dental examination was performed by the same evaluator who was calibrated on the assessment of oral health indicators by a professional dentist before data collection. The examiner used noninvasive sterile and disposable dental instruments to determine the following characteristics and indicators. 1) A survey of the participant's oral health status: on a schematic view of the mouth, every tooth was marked if decayed, filled, missing or crowned. When the participant wore a denture, the teeth replaced in the denture, and the type of denture (complete vs partial) were recorded. 2) DMFT Index (21): an accurate count of the total number of decayed, missing, and filled teeth. 3) Root Caries Index (RCI) (22): the number of radicular caries calculated by dividing the number of filled or decayed root surfaces by all visible root surfaces. 4) Plaque Index (PI) (23): evaluating the oral hygiene by recording both soft and mineralized deposits on the 4 surfaces (mesial, distal, buccal and lingual) of 6 teeth with a score ranging from 0 (no plaque) to 3 (abundance of soft matter on the tooth and gingival margin). 5) Periodontal Screening and Recording (PSR) (24): assessing the periodontal health, taking into account pocket depth, furcation involvement, tooth mobility, mucogingival problems and recession. The score ranges from 0 (healthy periodontium) to 4 (severe periodontal problem). 6) Functional Unit (FU) $(25,26)$ : number of mandibular teeth involved in mastication counted using articulating paper to mark the contacting mandibular and maxillary teeth. Every anterior tooth was considered 1 FU while premolars and molars were counted as 2 FUs each. All natural and restored teeth, including teeth in removable dentures, were counted.

A descriptive data analysis was performed for all the variables; frequency distributions were generated for categorical outcomes and the median/mean/standard deviation for continuous ones. Age was categorized according to World Health Organization (WHO) practices in 3 age groups: $65-74,75-84$ and $\geq 85$ years (27). All oral health indicators were compared according to gender, age and education. Nonparametric tests were used considering that the assumption of normality for the measures was not met. The bivariate associations between continuous measures of oral health outcome with gender were performed with the Mann-Whitney nonparametric test. The associations between the oral measures and variables of age, education and denture groups (no, complete and partial dentures), were gauged with the Kruskal-Wallis test. For categorical indicators, the $\chi^{2}$ test was used to evaluate the associations with age and gender. The calibration reliability between examiners was evaluated with the kappa coefficient; the inter-rater agreement was very high $(0.88<\mathrm{r}<0.98)$ for all measures. All the analyses were performed using Stata version 12.1.

Ethical approval was granted by the Institutional Review Board (IRB) at the American University of Beirut (FHS.LG.17). Every consenting participant was given appropriate instructions specific to their dental status (in terms of oral care and treatment need) and was provided with a list of centres delivering affordable oral treatments. Participants in need of treatment were referred to the centre closest to their homes. An IRB-approved flyer detailing how to keep healthy teeth and dentures, and care for the oral cavity was distributed to all participants.

\section{Results}

The average age of the participants was 73 (standard deviation 7.03 ) years; almost $40 \%$ of them between 71 and 80 years, around a third between 65 and 70 years, and a quarter $>80$ years. The majority $(\sim 70 \%)$ were women (Table 1).

On average, the missing teeth count was 19.6, and the FU count was nearly a third lower (7.5; range 0-22) than the functional norm of 20 FUs (Table 1$)$. The periodontal status was reflected by a mean PSR score per sextant of 1.01 and a PI of 1.96. Three-quarters of the sites had a PI of $\leq$ 2. The average RCI was 0.3; however, the median RCI was null. Most of the remaining teeth were mandibular, with more in the anterior (incisors and canines) than posterior (premolars and molars) regions. The remaining maxillary teeth were equally anterior or posterior. More than half of participants wore dentures (54.83\%), predominantly complete $(39.77 \%)$ and partial $(15.06 \%)$. Most participants (80.68\%) were edentulous ( $<21$ remaining teeth), of whom $25 \%$ had unrestored edentulism with an FU count of $0 ; 33.45 \%$ did not wear any dentures. The number of FU 


\begin{tabular}{|c|c|c|c|c|c|c|c|}
\hline & \multicolumn{2}{|c|}{$\begin{array}{l}\text { Total sample } \\
\qquad(n=352)\end{array}$} & \multicolumn{2}{|c|}{$\begin{array}{c}\text { Male } \\
(n=106)\end{array}$} & \multicolumn{2}{|c|}{$\begin{array}{l}\text { Female } \\
(n=246)\end{array}$} & \multirow[t]{2}{*}{$P^{*}$} \\
\hline & n & $\%$ & $n$ & $\%$ & n & $\%$ & \\
\hline No denture & 159 & 45.17 & 54 & 33.96 & 105 & 66.04 & 0.330 \\
\hline Partial denture & 53 & 15.06 & 13 & 24.53 & 40 & 75.47 & \\
\hline \multirow[t]{2}{*}{ Full denture } & 140 & 39.77 & 39 & 27.86 & 101 & 72.14 & \\
\hline & $n^{\mathrm{a}}$ & Mean (SD) & $n^{a}$ & Mean (SD) & $n^{\mathrm{a}}$ & Mean (SD) & \\
\hline PSR & 179 & $1.01(1.25)$ & 54 & $1.16(1.27)$ & 125 & $0.95(1.24)$ & 0.260 \\
\hline RCI & 181 & $0.30(0.38)$ & 55 & $0.34(0.40)$ & 126 & $0.28(0.38)$ & 0.290 \\
\hline Roots exposed & 181 & $4.49(4.08)$ & 55 & $5.16(4.32)$ & 126 & $4.20(3.99)$ & 0.120 \\
\hline Roots decayed/filled & 181 & $1.77(2.91)$ & 55 & $2.02(2.66)$ & 88 & $1.67(3.01)$ & 0.160 \\
\hline FU & 352 & $7.48(5.17)$ & 106 & $6.53(5.20)$ & 246 & $7.89(5.11)$ & 0.020 \\
\hline $\mathrm{D}$ & 352 & $1.51(2.95)$ & 106 & $1.53(2.47)$ & 246 & $1.51(3.13)$ & 0.430 \\
\hline M & 352 & $19.60(9.89)$ & 106 & $19.61(10.07)$ & 246 & $19.59(9.83)$ & 0.980 \\
\hline $\mathrm{F}$ & 352 & $2.24(4.08)$ & 106 & $1.53(3.30)$ & 246 & $2.54(4.35)$ & 0.080 \\
\hline DMFT & 352 & $23.35(6.57)$ & 106 & $22.67(7.37)$ & 246 & $23.64(6.18)$ & 0.580 \\
\hline Total PI & 172 & $1.96(0.81)$ & 51 & $2.14(0.81)$ & 121 & $1.89(0.80)$ & 0.056 \\
\hline Upper anterior & 352 & $2.05(2.66)$ & 106 & $2.11(2.64)$ & 246 & $2.02(2.67)$ & 0.590 \\
\hline Upper posterior & 352 & $2.05(2.93)$ & 106 & $2.12(2.97)$ & 246 & $2.02(2.92)$ & 0.790 \\
\hline Lower anterior & 352 & $2.39(2.77)$ & 106 & $2.25(2.72)$ & 246 & $2.45(2.79)$ & 0.670 \\
\hline Lower posterior & 352 & $2.32(3.17)$ & 106 & $2.27(3.17)$ & 246 & $2.35(3.17)$ & 0.900 \\
\hline
\end{tabular}

*Mann-Whitney U test.

${ }^{a}$ Differences in $n$ reflect the missing teeth in the corresponding category.

$D=$ decayed DMFT = decayed, missing and filled teeth; $F=$ filled; FU = functional units; $M$ = missing; PI = Plaque Index; PSR = Periodontal Screening and Recording; RCI = Root Caries Index; SD = standard deviation.

teeth were significantly greater in women than in men. PI was higher in men but the difference between the sexes was borderline significant.

Age was significantly related to DMFT score, which increased with age (mainly the missing component), and to the number of remaining mandibular anterior and maxillary posterior teeth, which decreased with age (Table 2). PSR differed significantly between the 2 younger age groups;PIdid not,althoughitshowed a pattern of reduction with age. Comparisons among denture groups revealed significant differences between no denture and complete denture wearers for all variables; between complete and partial denture wearers for all variables except FU; and between nodenture and partial denture groups only for the D component of the DMFT (Table 3).

Many variables (RCI, FU, DMFT, upper anterior and posterior teeth, lower posterior teeth) were significantly related to educational status (Table 4). RCI was lowest among people with college education, followed by those with secondary education. The highest numbers of FUs were found in college-educated older people. The numbers of remaining teeth and DMFT scores were the lowest among participants who were illiterate. The higher the education achieved, the more likely were people to retain their natural teeth versus wearing a denture.

\section{Discussion}

The poor oral health status disclosed in our population of community-dwelling older people was underlined through indices that revealed compromised functionality of the masticatory system. The increased number of missing teeth, mostly posterior, and the low FU count, reflect nonfunctional natural occlusion. However, most of these people wore replacement prostheses, with complete dentures outnumbering partial dentures, indicating that, even if prevention of dental/oral disease was lacking in younger study participants, an acceptable (although not necessarily optimal) remedy precluded the neglect of functionality compatible with basic tenets of quality of life. This premise would require dedicated research on oral health-related quality of life, in which the quality and functionality of the prostheses would also be assessed. Nevertheless, $33.45 \%$ of the edentulous older people ( $<21$ teeth remaining), $25 \%$ of whom had an FU count of 0 , did not use any partial or complete dentures, indicating inability to access dental care and absence of basic dental health plans for older people. In fact, dental insurance is available for only about $20 \%$ of the total population in Lebanon (13). These results may also be related to fear of dental treatment, neglect, and lack of awareness about proper dental care.

The observed major burden of missing teeth is in line with the national and global literature (28). The edentulism rate in our study (54\%) was between the lower 


\begin{tabular}{|c|c|c|c|c|c|c|c|c|c|}
\hline & \multicolumn{2}{|c|}{$(n=352)$} & \multicolumn{2}{|c|}{$\begin{array}{l}\text { Age } 65-74 \text { yr } \\
\qquad(n=204)\end{array}$} & \multicolumn{2}{|c|}{$\begin{array}{l}\text { Age } 75-84 \text { yr } \\
\qquad(n=124)\end{array}$} & \multicolumn{2}{|c|}{$\begin{aligned} \text { Age } & \geq 85 \mathrm{yr} \\
(n & =24)\end{aligned}$} & \multirow[t]{2}{*}{$P^{*}$} \\
\hline & n & Mean (SD) & $\mathbf{n}$ & Mean (SD) & n & Mean (SD) & n & Mean (SD) & \\
\hline PSR & 179 & $1.01(1.25)$ & 113 & $1.21(1.45)$ & 59 & $0.73(1.19)$ & 7 & $0.79(0.76)$ & 0.045 \\
\hline RCI & 181 & $0.30(0.38)$ & 114 & $0.33(0.39)$ & 60 & $0.24(0.37)$ & 7 & $0.24(0.40)$ & 0.230 \\
\hline Roots exposed & 181 & $4.49(4.08)$ & 114 & $4.54(4.05)$ & 60 & 4.38 (4.19) & 7 & $4.71(4.31)$ & 0.920 \\
\hline Roots D/F & 181 & $1.77(2.91)$ & 114 & $1.91(2.81)$ & 60 & $1.58(3.20)$ & 7 & $1.14(1.68)$ & 0.270 \\
\hline FU & 352 & $7.48(5.17)$ & 204 & $7.36(4.96)$ & 124 & $7.73(5.52)$ & 24 & $7.25(5.25)$ & 0.790 \\
\hline D & 352 & $1.51(2.95)$ & 204 & $1.73(3.02)$ & 124 & $1.27(2.93)$ & 24 & $0.96(2.27)$ & 0.120 \\
\hline M & 352 & 19.60 (9.89) & 204 & 18.54 (9.92) & 124 & 20.60 (9.90) & 24 & $23.42(8.22)$ & 0.030 \\
\hline $\mathrm{F}$ & 352 & $2.24(4.08)$ & 204 & $2.28(4.14)$ & 124 & $2.22(4.02)$ & 24 & $1.92(4.06)$ & 0.490 \\
\hline DMFT & 352 & $23.35(6.57)$ & 204 & $22.55(6.98)$ & 124 & $24.08(6.04)$ & 24 & $26.29(4.03)$ & 0.010 \\
\hline Total PI & 172 & $1.96(0.81)$ & 109 & $2.06(0.82)$ & 56 & $1.79(0.75)$ & 7 & $1.83(0.90)$ & 0.120 \\
\hline Upper anterior & 352 & $2.05(2.66)$ & 204 & $2.34(2.72)$ & 124 & $1.75(2.55)$ & 24 & $1.17(2.33)$ & 0.060 \\
\hline Upper posterior & 352 & $2.05(2.93)$ & 204 & $2.27(2.98)$ & 124 & $1.91(2.93)$ & 24 & $0.96(2.22)$ & 0.040 \\
\hline Lower anterior & 352 & $2.39(2.77)$ & 204 & $2.78(2.82)$ & 124 & $1.94(2.61)$ & 24 & $1.42(2.52)$ & 0.006 \\
\hline Lower posterior & 352 & $2.32(3.17)$ & 204 & $2.53(3.16)$ & 124 & $2.07(3.12)$ & 24 & $1.83(3.42)$ & 0.150 \\
\hline
\end{tabular}

${ }^{*}$ Kruskal-Wallis test.

+ Differences in $n$ reflect the missing teeth in the corresponding category.

Statistically significant differences: between people aged 65-74 years and 75-84 years for PSR scores; between people aged 65-74 years and $\geq 85$ years for DMFT score, number of missing teeth and number of remaining upper posterior teeth; between people aged 65-74 years and both other groups for the remaining lower anterior teeth.

No significant differences among the other age groups.

$\mathrm{D}=$ decayed DMFT = decayed, missing and filled teeth; $F=$ filled $; \mathrm{FU}=$ functional units; $M=$ missing; $P S R=$ Periodontal Screening and Recording; $R C I=$ Root Caries Index; $S D=$ standard deviation.

rate $(41.2 \%)$ reported by Farhat-Mechayleh et al. (19) and higher prevalence observed by El Helou et al. (69.6\%) in a hospital-based study (16). The current findings were compared with similar assessments from other countries, particularly the surrounding Middle East and North Africa (MENA) Region, using American data as a benchmark because of the availability of basic dental coverage for older people (Figure 1). Only DMFT scores were available for a number of countries (Figure 1A). Dental plaque, FU and RCI were not commonly evaluated in the MENA Region; therefore, comparisons were made with western countries (Figure $1 \mathrm{~B}-\mathrm{D})$.

The number of older people retaining at least 20 teeth in this study (21.59\%) was markedly lower than the millennium goals set by the World Dental Federation to have in $2000 \geq 50 \%$ of older adults aged 65 years retain no fewer than 20 teeth (29). The $25 \%$ rate of unrestored edentulism among those with $<21$ remaining teeth was high, close to the rates found by El Helou et al. (21\%) (16) and El Osta et al. (22\%) (30), but lower than the $33 \%$ reported by Farhat Mechayleh et al. (19).

The average number of decayed and filled teeth (3.75) is midway between international and regional numbers, which range from 2.5 to $5.7(31,32)$. The data differ within subcategories when compared with other reports on Lebanese older people: 1.51 decayed and 18.6 missing teethcomparedwithcorrespondingnumbersreportedbyEl Osta et al. (3.32 and 17.8, respectively) (15). The lower number of decayed teeth in our study may be associated with thehighernumberofmissingteeth,ontheassumption that severely decayed teeth were lost or extracted.

\begin{tabular}{|c|c|c|c|c|c|c|c|}
\hline & \multicolumn{2}{|c|}{ No denture $^{a}$} & \multicolumn{2}{|c|}{ Partial denture } & \multicolumn{2}{|c|}{ Complete denture } & \multirow[t]{2}{*}{$P^{*}$} \\
\hline & $n$ & Mean (SD) & $n$ & Mean (SD) & $n$ & Mean (SD) & \\
\hline FU & 159 & $6.12(5.47)$ & 53 & $7.85(4.54)$ & 140 & $8.89(4.65)$ & 0.0001 \\
\hline $\mathrm{D}$ & 159 & $2.81(3.68)$ & 53 & $1.60(2.49)$ & 140 & $0.01(0.08)^{\mathrm{a}}$ & 0.0001 \\
\hline M & 159 & $12.86(9.67)$ & 53 & $17.72(6.66)$ & 140 & $27.96(0.28)^{\mathrm{a}}$ & 0.0001 \\
\hline $\mathrm{F}$ & 159 & $3.95(5.03)$ & 53 & $2.94(3.60)$ & 140 & $0.21(0.25)^{\mathrm{a}}$ & 0.0001 \\
\hline DMFT & 159 & $19.62(7.17)$ & 53 & $22.26(5.78)$ & 140 & $27.99(0.08)^{\mathrm{a}}$ & 0.0001 \\
\hline
\end{tabular}

\section{${ }^{*}$ Kruskal-Wallis}

${ }^{a}$ Teeth counts in the DMFT score and its components in the complete denture group relate to the finding of remnants of teeth under the dentures in some participants.

Statistically significant differences: between no denture wearers and complete denture wearers $(P<0.001)$ for all variables; between complete and partial denture wearers $(P<0.001)$ for all variables except $F U$; between no denture and partial denture groups only for the $D$ component of the DMFT $P=0.047$ ).

$D=$ decayed $; D M F T=$ decayed, missing and filled teeth; $F=$ filled; $M=$ missing; $S D=$ standard deviation . 


\begin{tabular}{|c|c|c|c|c|c|c|c|c|c|c|c|c|c|}
\hline \multirow[t]{2}{*}{$\begin{array}{l}\text { Oral health } \\
\text { status indicator }\end{array}$} & \multicolumn{2}{|c|}{$\begin{array}{l}\text { Illiterate } \\
(n=73)\end{array}$} & \multicolumn{2}{|c|}{$\begin{array}{c}\text { Basic literacy } \\
\quad(\mathbf{n}=\mathbf{3 0})\end{array}$} & \multicolumn{2}{|c|}{$\begin{array}{l}\text { Primary } \\
(n=129)\end{array}$} & \multicolumn{2}{|c|}{$\begin{array}{c}\text { Complementary } \\
(n=57)\end{array}$} & \multicolumn{2}{|c|}{$\begin{array}{l}\text { Secondary } \\
(n=36)\end{array}$} & \multicolumn{2}{|c|}{$\begin{array}{l}\text { College } \\
(n=27)\end{array}$} & \multirow[b]{2}{*}{$P^{*}$} \\
\hline & $\mathbf{n}$ & $\begin{array}{l}\text { Mean } \\
\text { (SD) }\end{array}$ & $\mathbf{n}$ & $\begin{array}{l}\text { Mean } \\
\text { (SD) }\end{array}$ & $\mathbf{n}$ & $\begin{array}{l}\text { Mean } \\
\text { (SD) }\end{array}$ & $\mathbf{n}$ & $\begin{array}{l}\text { Mean } \\
\text { (SD) }\end{array}$ & n & $\begin{array}{l}\text { Mean } \\
\text { (SD) }\end{array}$ & n & $\begin{array}{c}\text { Mean } \\
\text { (SD) }\end{array}$ & \\
\hline PSR & 19 & $\begin{array}{r}3.68 \\
(4.60)\end{array}$ & 11 & $\begin{array}{r}4.18 \\
(4.94)\end{array}$ & 39 & $\begin{array}{r}4.54 \\
(4.54)\end{array}$ & 22 & $\begin{array}{r}5.77 \\
(7.07)\end{array}$ & 15 & $\begin{array}{r}3.27 \\
(5.78)\end{array}$ & 22 & $\begin{array}{r}6.27 \\
(7.11)\end{array}$ & 0.6600 \\
\hline $\mathrm{RCI}^{\mathrm{a}}$ & 19 & $\begin{array}{r}0.40 \\
(0.45)\end{array}$ & 11 & $\begin{array}{r}0.53 \\
(0.44)\end{array}$ & 39 & $\begin{array}{r}0.33 \\
(0.34)\end{array}$ & 23 & $\begin{array}{r}0.49 \\
(0.44)\end{array}$ & 15 & $\begin{array}{r}0.03 \\
(0.10)\end{array}$ & 22 & $\begin{array}{r}0.09 \\
(0.15)\end{array}$ & 0.0001 \\
\hline Roots exposed & 19 & $\begin{array}{r}4.00 \\
(4.68)\end{array}$ & 11 & $\begin{array}{r}5.82 \\
(5.69)\end{array}$ & 39 & $\begin{array}{r}5.08 \\
(3.33)\end{array}$ & 23 & $\begin{array}{r}5.83 \\
(4.12)\end{array}$ & 15 & $\begin{array}{r}3.67 \\
(4.84)\end{array}$ & 22 & $\begin{array}{r}4.64 \\
(4.45)\end{array}$ & 0.1600 \\
\hline $\begin{array}{l}\text { Roots decayed/ } \\
\text { filled }^{\mathrm{b}}\end{array}$ & 19 & $\begin{array}{r}2.42 \\
(3.44)\end{array}$ & 11 & $\begin{array}{r}3.64 \\
(5.24)\end{array}$ & 39 & $\begin{array}{r}2.23 \\
(3.06)\end{array}$ & 23 & $\begin{array}{r}2.65 \\
(3.32)\end{array}$ & 15 & $\begin{array}{r}0.13 \\
(0.52)\end{array}$ & 22 & $\begin{array}{r}0.55 \\
(0.91)\end{array}$ & 0.0004 \\
\hline $\mathrm{FU}^{\mathrm{c}}$ & 73 & $\begin{array}{r}6.75 \\
(4.86)\end{array}$ & 30 & $\begin{array}{r}6.40 \\
(5.21)\end{array}$ & 129 & $\begin{array}{r}7.50 \\
(5.13)\end{array}$ & 57 & $\begin{array}{r}7.16 \\
(5.67)\end{array}$ & 36 & $\begin{array}{r}7.89 \\
(4.89)\end{array}$ & 27 & $\begin{array}{l}10.70 \\
(4.47)\end{array}$ & 0.0160 \\
\hline D & 25 & $\begin{array}{r}3.52 \\
(4.61)\end{array}$ & 13 & $\begin{array}{r}2.85 \\
(2.70)\end{array}$ & 54 & $\begin{array}{r}2.96 \\
(3.49)\end{array}$ & 28 & $\begin{array}{r}3.50 \\
(4.93)\end{array}$ & 16 & $\begin{array}{r}1.75 \\
(2.27)\end{array}$ & 23 & $\begin{array}{r}1.57 \\
(1.90)\end{array}$ & 0.5400 \\
\hline M & 25 & $\begin{array}{l}14.92 \\
(9.83)\end{array}$ & 13 & $\begin{array}{l}16.08 \\
(9.15)\end{array}$ & 54 & $\begin{array}{l}15.28 \\
(9.43)\end{array}$ & 28 & $\begin{array}{r}12.64 \\
(9.67)\end{array}$ & 16 & $\begin{array}{r}8.25 \\
(9.15)\end{array}$ & 23 & $\begin{array}{r}6.57 \\
(7.24)\end{array}$ & 0.0001 \\
\hline $\mathrm{F}$ & 25 & $\begin{array}{r}3.28 \\
(4.61)\end{array}$ & 13 & $\begin{array}{r}3.08 \\
(3.93)\end{array}$ & 54 & $\begin{array}{r}3.20 \\
(5.44)\end{array}$ & 28 & $\begin{array}{r}2.61 \\
(3.92)\end{array}$ & 16 & $\begin{array}{r}5.75 \\
(4.12)\end{array}$ & 23 & $\begin{array}{r}7.30 \\
(5.42)\end{array}$ & 0.0029 \\
\hline DMFT $^{d}$ & 25 & $\begin{array}{r}21.72 \\
(6.30)\end{array}$ & 13 & $\begin{array}{l}22.00 \\
(5.63)\end{array}$ & 54 & $\begin{array}{r}21.44 \\
(6.56)\end{array}$ & 28 & $\begin{array}{r}18.75 \\
(8.36)\end{array}$ & 16 & $\begin{array}{l}15.75 \\
(7.13)\end{array}$ & 23 & $\begin{array}{l}15.43 \\
(6.14)\end{array}$ & 0.0016 \\
\hline Total Plaque Index & 25 & $\begin{array}{r}2.09 \\
(0.84)\end{array}$ & 14 & $\begin{array}{r}2.18 \\
(0.76)\end{array}$ & 57 & $\begin{array}{r}1.99 \\
(0.79)\end{array}$ & 28 & $\begin{array}{r}2.10 \\
(0.85)\end{array}$ & 23 & $\begin{array}{r}1.70 \\
(0.68)\end{array}$ & 25 & $\begin{array}{r}1.73 \\
(0.87)\end{array}$ & 0.2100 \\
\hline Upper anterior & 25 & $\begin{array}{r}3.36 \\
(2.63)\end{array}$ & 13 & $\begin{array}{r}3.38 \\
(2.50)\end{array}$ & 54 & $\begin{array}{r}3.43 \\
(2.59)\end{array}$ & 28 & $\begin{array}{r}3.93 \\
(2.64)\end{array}$ & 16 & $\begin{array}{r}4.56 \\
(2.39)\end{array}$ & 23 & $\begin{array}{r}5.52 \\
(1.38)\end{array}$ & 0.0030 \\
\hline Upper posterior $^{\mathrm{f}}$ & 25 & $\begin{array}{r}3.12 \\
(2.68)\end{array}$ & 13 & $\begin{array}{r}3.31 \\
(3.57)\end{array}$ & 54 & $\begin{array}{r}3.09 \\
(2.90)\end{array}$ & 28 & $\begin{array}{r}4.11 \\
(3.02)\end{array}$ & 16 & $\begin{array}{r}5.38 \\
(2.94)\end{array}$ & 23 & $\begin{array}{r}6.13 \\
(2.62)\end{array}$ & 0.0008 \\
\hline Lower anterior & 25 & $\begin{array}{r}3.44 \\
(2.62)\end{array}$ & 13 & $\begin{array}{r}3.38 \\
(2.40)\end{array}$ & 54 & $\begin{array}{r}3.54 \\
(2.73)\end{array}$ & 28 & $\begin{array}{r}4.11 \\
(2.75)\end{array}$ & 16 & $\begin{array}{r}5.19 \\
(1.64)\end{array}$ & 23 & $\begin{array}{r}4.78 \\
(2.17)\end{array}$ & 0.0920 \\
\hline Lower posteriorg & 25 & $\begin{array}{r}3.52 \\
(3.10)\end{array}$ & 13 & $\begin{array}{r}3.00 \\
(2.94)\end{array}$ & 54 & $\begin{array}{r}3.39 \\
(3.06)\end{array}$ & 28 & $\begin{array}{r}4.07 \\
(3.30)\end{array}$ & 16 & $\begin{array}{r}5.94 \\
(3.77)\end{array}$ & 23 & $\begin{array}{r}6.09 \\
(2.86)\end{array}$ & 0.0030 \\
\hline
\end{tabular}

${ }^{*}$ Kruskal-Wallis test

Post hoc results:

${ }^{a, b}$ SSD between (1) college attendees and all the others except illiterate and participants with secondary education; and (2) participants with secondary education and all others except college attendees.

'SSD between college attendees and all other groups except participants with secondary education.

${ }^{d} S S D$ between the illiterate college groups.

e,fSSD between illiterate participants and those who reached primary and college educational levels.

${ }^{9} S S D$ between illiterate seniors and those with primary education.

$D=$ decayed $; D M F T=$ decayed, missing and filled teeth; F = filled; FU = functional units; $M=$ missing; PSR = Periodontal Screening and Recording; RCI = Root Caries Index SD = standard deviation; SSD = statistically significant difference.

The PSR score and low PI indicate acceptable periodontal and oral hygiene status, but the high number of missing teeth may have resulted from poor prior periodontal health that led to the observed edentulism. More mandibular anterior teeth remained, compared with all other teeth, possibly because of their protected position in the mouth.

The lack of gender differences, except for the higher FUs in women, is not in line with the published literature $(18,29,32)$. This difference may be ascribed to the fact that men and women in our study received the same level of care and follow-up. Also, it is plausible that the high number of missing teeth camouflaged data that are otherwise better depicted by oral health indices.

The increase in tooth loss and periodontal diseases with age agrees with previous studies $(28,29)$. In contrast, our findings on root caries were not in line with the reported increase with age (33). The reduction in the periodontal indices (PI and PSR) was not significantly different between the older age groups. This finding may be associated with the increased number of missing teeth with age, which resulted in the lower number of remaining teeth being assessed for periodontal status. The association between oral health and education reflecting better oral condition in the more-educated older people corresponds to already established links (3).

The target of geriatric healthcare is to provide functionality and optimalquality of life topeoplebecoming more vulnerable with age. Accordingly, the primary focus is on the necessary FUs that support painless masticatory function (and appropriate speech) compatible with health and non-interference of oral problems with normal activities and dignity in older people. Research is needed 
Figure 1 Comparison of the investigated DMFT (A), Plaque Index (B), FUs (C) and RCI (D) with published outcomes from similar communities of different countries, benchmarked against US scores except for the FUs (C) where the optimal comparison was with data in Spain because of similar assessment of this variable, although the removable dentures were not included in the Spanish score, which would have been otherwise higher. Note that DMFT scores are lower in the USA than any scores available from Arab countries, probably because of greater access to dental services that would prevent dental problems and allow seniors to retain healthy teeth for a longer time. DMFT = decayed, missing and filled teeth; FU = functional units; RCI = Root Caries Index.

DMFT

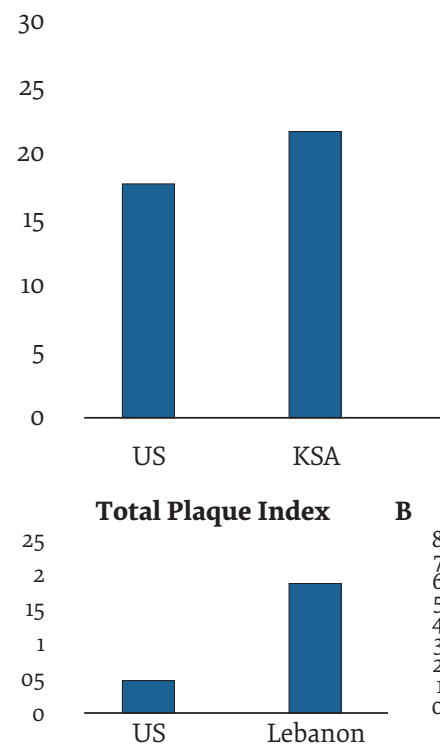

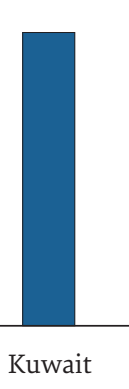

8
7
6
5
4
3
2
1
0
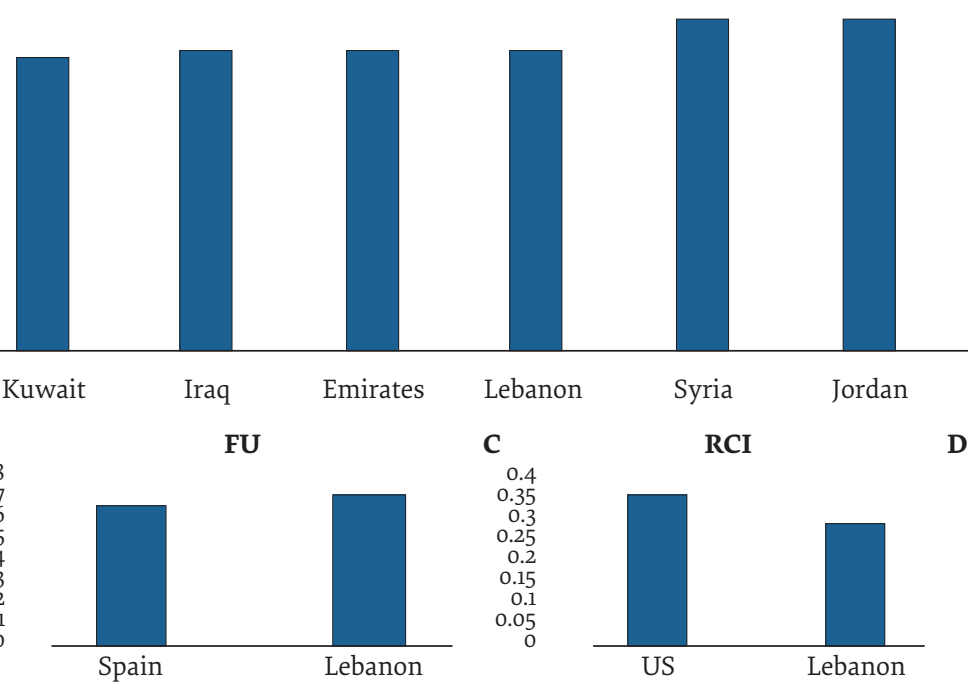

RCI

D

\footnotetext{
Sources: Dye BA, Tan S, Smith V, Lewis B, Barker L, Thornton-Evans G, et al. Trends in oral health status: United States, 1988-1994 and 1999-2004. Vital Health Stat 11. 2007 Apr;(248):1-92. PMID:17633507

Wiener RC, Wu B, Crout RJ, Plassman BL, McNeil DW, Wiener MA, et al. Hygiene self-care of older adults in West Virginia: effects of gender. J Dent Hyg. 2012 Summer;86(3):231-8. PMID:22947846

Al-Taweel AF, Qasim AA. Caries experience among Parkinson's disease patients in Baghdad-Iraq. Int J Sci Res. 2017;6(6):2788-91

Behbehani JM, Shah NM. Oral health in Kuwait before the Gulf War. Med Princ Pract. 2002;11(Suppl 1):36-43. https://doi.org/10.1159/000057777 PMID:12123115

Almazrooei B, Rad FA, Milosevic A. The oral health status of attendees and residents in united arab emirates care homes. J Int Soc Prev Community Dent. 2020 Feb 11;10(1):101-6. https://doi. org/10.4103/jispcd.JISPCD_349_19 PMID:32181227

World Health Organization. Oral health country/area profile programme who headquarters geneva. Oral Health Programme (NPH) WHO Collaborating Centre, Malmö University, Sweden AlHadidi A, Bustani M, Ammarin R, Afaneh D, Kokash A, Naser R, et al. DMFT index in a tertiary care center in Amman, Jordan. Jordan Med J. 2019;53(1):37-43.

AlBaker AM, AlBaqami FF, AlHarbi TM, AlAmri MD, Baskaradoss JK. Oral health status and oral health-related quality of life among hospitalized and nonhospitalized geriatric patients. J Contemp Dent Pract. 2017 Mar 1;18(3):228-34. PMID:28258270

Barrios R, Bravo M, Gil-Montoya JA, Martínez-Lara I, García-Medina B, Tsakos G. Oral and general health-related quality of life in patients treated for oral cancer compared to control group. Health Qual Life Outcomes. 2015 Jan 23;13:9. https://doi.org/10.1186/s12955-014-0201-5 PMID:25613348
}

to standardize the definition of $\mathrm{FU}$ (anterior, posterior and combined segments), its differential weight (double or single weight for posterior teeth contacts), its relationship to restorations, and its application in a way similar to DMFT. FU is high when a denture restores occlusion and mastication, and low without this restoration. The quality of dentures may also be explored. Thus, a functional index should be developed to objectively quantify chewing ability and comfort or pain, possibly a standardized FU added to chewing ability and associated comfort and pain. Comparisons across countries and healthcaresystemsmay then reflect the optimal oral care in older people.

The current study has its limitations and offsetting strengths. The cross-sectional nature of the study means that temporal or causal inferences cannot be made, and the convenientsamplingconfined toanurbanpopulationinthe Greater Beirut area precludes making any generalizations to the entire older population of Lebanon. Nonetheless, the study targeted older people from nondiscriminating social organizations, and therefore represents the population of community-dwelling older people within the capital and its suburbs. Moreover, the study included a comprehensive list of indicators that shed new light on geriatric health in Lebanon and allowed for comparisons with regional and international geriatric data as well as the recommendation to standardize the evaluation of FUs.

The calibration of oral health assessment by an experienced dentist before data collection enhanced the validity of the findings. The Community Periodontal Index of Treatment Needs, recommended by WHO, was not used, reducing comparability with other published data. However, the PSR provided information about tooth mobility, furcation involvement and recession; all symptoms expected to occur with periodontal disease particularly in an aged population (34). Another limitation is that some conditions such as xerostomia, oral cancer, mucosal lesions, and oral and temporomandibular joint pain were not factored in the analyses; they were not within the scope of the research and would require longer and more advanced examinations.

The findings of high oral health burden invite action from policy-makers and government agencies to prioritize oral health awareness, prevention and treatment for people who have already contributed 
to society through long-term work and parenting. A national data registry following WHO guidelines should be established to periodically collect data on various indicators within diverse segments of the population from different socioeconomic levels, including oral health risk factors such as general health condition, smoking status, nutritional information, oral hygiene practice and other details known to be associated with oral health. Problems in mastication, oral dysfunction, discomfort and related psychological issues can affect general health. By recognizing that oral health is part of total health, relevant authorities should aim to provide affordable essential care for older people and integrate it into general health insurance schemes (35). Oral health awareness campaigns could be integrated into general health campaigns and medical care instructions provided by physicians and hospitals.

Until national programmes are developed, smaller steps may be based on prioritizing problems associated with missing teeth and low FUs. Accessibility to dental care could be increased through the allocation of dentists to social organizations that provide health services to older people. Dentists, especially new graduates, should be encouraged to treat older people, hopefully motivated by the developed competence in geriatric dentistry increasingly embedded in dental schools' curricula. Emphasis on improved quality of care in private and public arenas should be accompanied with education on oral disease and means of prevention and change of unhealthy behaviours, as well as early prevention at younger ages underlining the need for regular professional care.

\section{Conclusions}

Community-dwelling older people in urban Lebanon experienced mainly loss of teeth, associated low FUs, and correspondingly acceptable but camouflaging decay levels and periodontal health. The results disclose the lack of national and institutional policies that should address this oral health burden by considering the inclusion of oral care as part of total health care in governmental and insurance programmes.

\section{Acknowledgement}

The authors acknowledge the Tabourian Educational Fund, Division of Orthodontics and Dentofacial Orthopedics for field support of the study, Dr. Jad Azar for his contribution in the data collection process, the International College of Dentistry, Middle East Section, for providing free instructional flyers, and GlaxoSmithKline for offering toothpastes to the participants.

\section{Funding: None}

Competing interests: None declared.

\section{État de santé bucco-dentaire dans une population gériatrique libanaise Résumé}

Contexte: La croissance constante du nombre des personnes âgées et la transition épidémiologique des problèmes de santé transmissibles aux problèmes de santé chroniques ont fait porter une attention accrue sur le bien-être gériatrique, y compris la santé bucco-dentaire.

Objectifs : Évaluer la santé bucco-dentaire des personnes âgées vivant dans les communautés urbaines et identifier leurs besoins prioritaires en matière de santé bucco-dentaire.

Méthodes: Nous avons recruté 352 adultes âgés de 65 ans et plus en 2015 auprès des organisations sociales et des centres de soins de santé primaires à Beyrouth et dans sa banlieue. Les personnes âgées se sont soumises à un examen dentaire comprenant l'indice DCAO (dents cariées, absentes et obturées), la santé gingivale [indice de plaque (IP) et de dépistage et d'enregistrement parodontal] et les unités dentaires fonctionnelles (UF). Des données socio-démographiques ont été collectées au moyen d'un questionnaire structuré lors d'un entretien en face à face. Les participants ont été stratifiés en trois tranches d'âge, et selon la restauration avec une prothèse dentaire partielle, complète ou sans prothèse. Les analyses statistiques comprenaient les tests de Mann-Whitney, Kruskal-Wallis et $\chi^{2}$ pour explorer l'état de santé bucco-dentaire en fonction des données sociodémographiques.

Résultats: Les dents manquantes étaient le principal élément qui contribuait à un indice DCAO élevé. Les indices IP et de caries radiculaires moyens étaient élevés. Les scores d'UF moyens étaient faibles, mais ils étaient plus élevés chez les femmes et les porteurs de prothèses complètes. Les tranches plus âgées présentaient un nombre plus faible de dents mandibulaires antérieures et maxillaires postérieures restantes, des indices DCAO plus élevés, mais un meilleur état parodontal (indice de dépistage et d'enregistrement parodontal plus faibles). Les participants les plus éduqués présentaient des indices plus sains.

Conclusion : Nous avons observé une mauvaise santé bucco-dentaire chez les personnes âgées ; cela concernait en particulier les dents manquantes et les scores UF faibles, nécessitant des interventions pour intégrer la santé buccodentaire dans le champ de la santé générale gériatrique. 


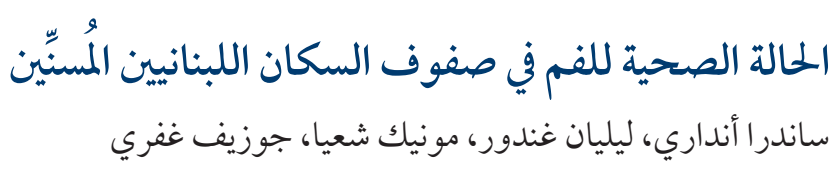

الخلاصة

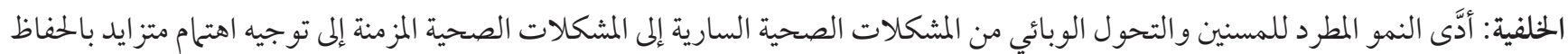

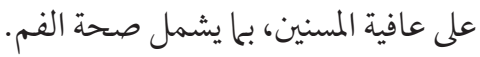

الأهداف: هدفت هذه الدراسة إلى تقييم صحة الفم في صفوف المسنين الذين يسكنون في المجتمعات الحضرية وتمبه وتحيد احتياجاتهم ذات الأولوية في

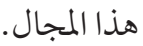

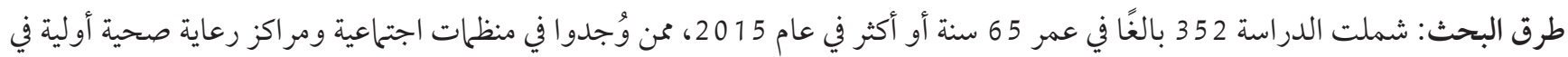

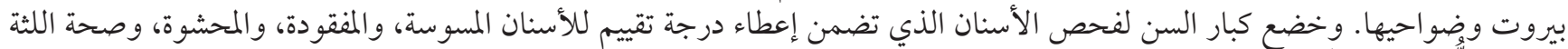

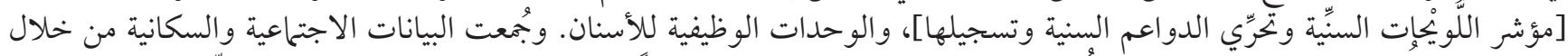

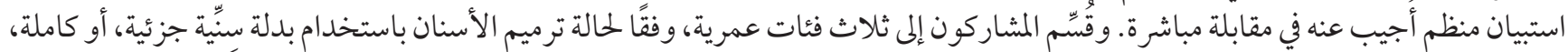

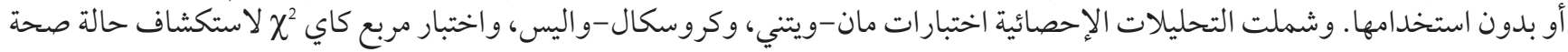
الفم حسب الخصائص الاجتماعية السكانية.

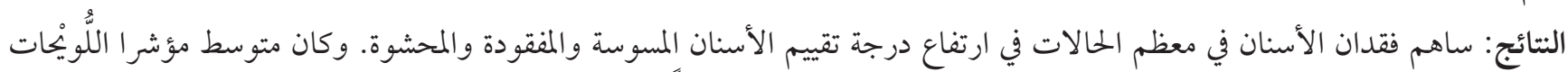

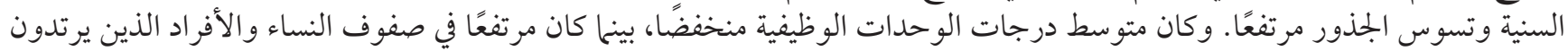

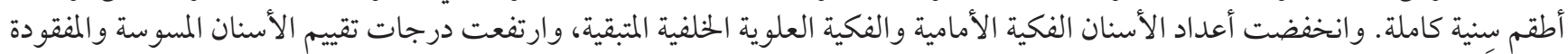

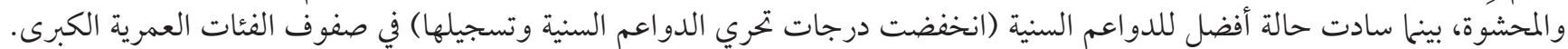

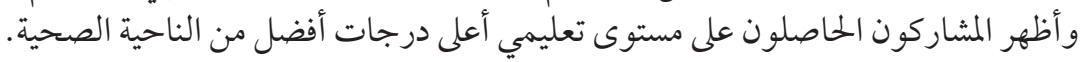

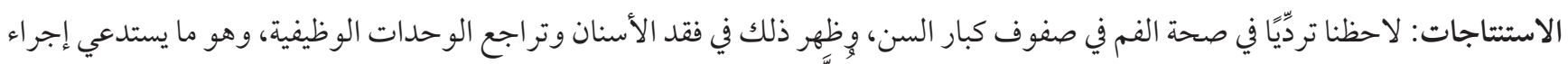
تدخلات لإدراج صحة الفم ضمن نطاق خدمات في الصات الصحة العامة المقدَّمة للمسنين.

\section{References}

1. Fuster V. Changing demographics: a new approach to global health care due to the aging population. J Am Coll Cardiol. 2017; Jun 20;69(24):3002-5. http://dx.doi.org/10.1016/j.jacc.2017.05.013 PMID:28619199

2. Allen L. Are we facing a noncommunicable disease pandemic? J Epidemiol Glob Health. 2017 Mar;7 (1):5-9. https://doi. org/10.1016/j.jegh.2016.11.001 PMID:27886846

3. Kossioni AE, Hajto-Bryk J, Maggi S, McKenna G, Petrovic M, RollerDWirnsberger RE, et al. An expert opinion from the European College of Gerodontology and the European Geriatric Medicine Society: European policy recommendations on oral health in older adults. J Am Geriatr Soc. 2018 Mar;66:(3) 609-13. https://doi.org/10.1111/jgs.15191 PMID:29266168

4. Gameiro GH, Magalhães IB, Szymanski MM, Andrade AS. Is the main goal of mastication achieved after orthodontic treatment? A prospective longitudinal study. Dental Press J Orthod. 2017 May-Jun;22(3):72-8. https://doi.org/10.1590/2177-6709.22.3.072-078. oar PMID:28746490

5. Dahl KE, Calogiuri G, Jönsson B. Perceived oral health and its association with symptoms of psychological distress, oral status and socio-demographic characteristics among elderly in Norway. BMC Oral Health. 2018 May 31;18(1):1-8. https://doi.org/10.1186/ S12903-018-0556-9 PMID:29855283

6. Hung M, Moffat R, Gill G, Lauren E, RuizछNegrón B, Rosales MN, et al. Oral health as a gateway to overall health and well $\square$ being: surveillance of the geriatric population in the United States. Spec Care Dentist. 2019 Jul;39(4):354-61. http://dx.doi. org/10.1111/scd.12385 PMID:31087569

7. Kronfol N. Access and barriers to health care delivery in Arab countries: a review. East Mediterr Health J. 2012 Dec;18(12):1239-46. PMID:23301399

8. Chahine MA, Sibai AM. The University of the Third Age in Lebanon: challenges, opportunities and prospects. The University of the Third Age and Active Ageing. Springer; 2019: 181-93. https://doi.org/10.1007/978-3-030-21515-6_15

9. Petersen P, Yamamoto T. Improving the oral health of older people: the approach of the WHO Global Oral Health Programme. Community Dent Oral Epidemiol. 2005 Apr;33(2):81-92. PMID:15725170

10. Petersen PE, Kandelman D, Arpin S, Ogawa H. Global oral health of older people-call for public health action. Community Dent Health. 2010 Dec;27(4 Suppl 2):257-67. PMID:15725170

11. Petersen PE, Ogawa H. Promoting oral health and quality of life of older people-the need for public health action. Oral Health Prev Dent. 2018;16(2):113-24. https://doi.org/10.3290/j.ohpd.a40309 PMID:29736489 
12. Doumit JH, Nasser RN, Hanna DR. Nutritional and health status among nursing home residents in Lebanon: comparison across gender in a national cross sectional study. BMC Public Health 2014;14(1):629. https://doi.org/10.1186/1471-2458-14-629

13. El Osta N, Hennequin M, El Osta L, Naaman NBA, Geahchan N, Tubert-Jeannin S. État des lieux sanitaire et bucco-dentaire de la population gériatrique libanaise. East Mediterr Health J. 2015;21(5):349-53. https://doi.org/10.26719/2015.21.5.349

14. El Osta N, Hennequin M, Tubert-Jeannin S, Naaman NBA, El Osta L, Geahchan N. The pertinence of oral health indicators in nutritional studies in the elderly. Clin Nutr. 2014 Apr;33(2):316-21. https://doi.org/10.1016/j.clnu.2013.05.012 PMID:23773972

15. El Osta N, Tubert S, Naaman N, Hennequin M, El Osta L, Geahchan N. Oral and general health indicators for Lebanese elderly in oral surveys: review article. Int Arab J Dent. 2012;3(2):54-61.

16. El Hélou M, Boulos C, Adib SM, Tabbal N. Relationship between oral health and nutritional status in the elderly: a pilot study in Lebanon. J Clin Gerontol Geriatr. 2014;5(3):91-5. https://doi.org/10.1016/j.jcgg.2014.04.002 PMID:22437676

17. Boulos C, Salameh P, Barberger-Gateau P. Factors associated with poor nutritional status among community dwelling Lebanese elderly subjects living in rural areas: results of the AMEL study. J Nutr Health Aging. 2014 May;18(5):487-94. https://doi. org/10.1007/s12603-014-0463-y PMID:24886735

18. Boulos C, Salameh P, Barberger-Gateau P. The AMEL study, a cross sectional population-based survey on aging and malnutrition in 1200 elderly Lebanese living in rural settings: protocol and sample characteristics. BMC Public Health. 2013;13(1):573. https:// doi.org/10.1186/1471-2458-13-573

19. Farhat-Mechayleh N, El-Osta N, Sleiman R, Tannous J, Tohme H, Boulos P. Statut bucco-dentaire au sein d'une population gériatrique Libanaise: étude pilote. Int Arab J Dent. 2011;2:(2):60-5. https://journals.usj.edu.lb/iajd/article/view/269

20. Phung KT, Chaaya M, Prince M, Atweh S, El Asmar K, Karam G, et al. Dementia prevalence, care arrangement, and access to care in Lebanon: a pilot study. Alzheimers Dement. 2017 Dec;13(12):1317-26. https://doi.org/10.1016/j.jalz.2017.04.007 PMID:28579315

21. Petersen P. The World Oral Health Report 2003: continuous improvement of oral health in the 21st century-the approach of the WHO Global Oral Health Programme. Community Dent Oral Epidemiol. 2003 Dec;31(Suppl 1):3-24. PMID:15015736

22. Katz RV. Assessing root caries in populations: the evolution of the root caries index. J Public Health Dent. 1980 Winter;40(1):7-16. PMID:6928495

23. Silness J, Löe H. Periodontal disease in pregnancy II. Correlation between oral hygiene and periodontal condition. Acta Odontol Scand. 1964 Feb;22(1):121-35. PMID:14158464

24. American Academy of Periodontology. Periodontal screening and recording system training manual. Chicago: American Academy of Periodontology; 1992.

25. Adiatman M, Ueno M, Ohnuki M, Hakuta C, Shinada K, Kawaguchi Y. Functional tooth units and nutritional status of older people in care homes in Indonesia. Gerodontology. 2013 Dec;30(4):262-9. https://doi.org/10.1111/j.1741-2358.2012.00673.x PMID:22607635

26. Samnieng P, Ueno M, Shinada K, Zaitsu T, Wright FAC, Kawaguchi Y. Oral health status and chewing ability is related to mini-nutritional assessment results in an older adult population in Thailand. J Nutr Gerontol Geriatr. 2011;30(3):291-304. https:// doi.org/10.1080/21551197.2011.591271 PMID:21846244

27. Oral health surveys: basic methods, 5th edition. Geneva: World Health Organization; 2013.

28. Polzer I, Schimmel M, Müller F, Biffar R. Edentulism as part of the general health problems of elderly adults. Int Dent J. 2010 Jun;60(3):143-55. PMID:20684439

29. Gaio EJ, Haas AN, Carrard VC, Oppermann RV, Albandar J, Susin C. Oral health status in elders from South Brazil: a populationbased study. Gerodontology. 2012 Sep;29(3):214-23. https://doi.org/10.1111/j.1741-2358.2011.00617.x. PMID:22486627

30. El Osta N, Tubert-Jeannin S, Hennequin M, Bou Abboud Naaman N, El Osta L, Geahchan N. Comparison of the OHIP-14 and GOHAI as measures of oral health among elderly in Lebanon. Health Qual Life Outcomes. 2012 Oct 30;10(131):1-10. https://doi. org/10.1186/1477-7525-10-131 PMID:23110518

31. Petersen P, Razanamihaja N, Poulsen V. Surveillance of oral health among children and adults in Madagascar. Geneva: World Health Organization; 2004.

32. Al-Shehri SA. Oral health status of older people in residential homes in Saudi Arabia. Open J Stomatol. 2012 Dec;2(4):307-13. https://doi.org/10.4236/ojst.2012.24053

33. Wu Y-F, Lee W-F, Salamanca E, Yao W-L, Su J-N, Wang S-Y, et al. Oral microbiota changes in elderly patients, an indicator of alzheimer's disease. INT J Environ Res Public Health. 2021 Apr 15;18(8):4211. https://doi.org/10.3390/ijerph18084211 PMID:33921182

34. Dhingra K, Vandana KL. Indices for measuring periodontitis: a literature review. Int Dent J. 2011 Apr;61(2):76-84. https://doi. org/10.1111/j.1875-595X.2011.00018.x PMID:21554276

35. Karam I, Jaffa M, Ghafari J. Barriers to the use of dental services by children in Lebanon and association with parental perception of oral health care. East Mediterr Health J. 2020 Nov 11;26(11):1420-4. https://doi.org/10.26719/emhj.20.079 PMID:33226111 